DOI https://doi.org/10.32782/2305-9389/2020.23.30

УДК 351.759.6

Федорова Анна,

аспірант кафедри публічного управління та менеджменту інноващійної діяльності

Навчально-наукового інституту післядипломної освіти

Національного університету біоресурсів та природокористування України

\title{
СУЧАСНИЙ СТАН ТА РЕКОМЕНДАЦІЇ ЩОДО УДОСКОНАЛЕННЯ МЕХАНІЗМІВ ВЗАЕМОДІЇ ОРГАНІВ ПУБЛІЧНОЇ ВЛАДИ З ГРОМАДСЬКІСТЮ ДЛЯ ФОРМУВАННЯ БЕЗПЕЧНОГО СЕРЕДОВИЩА ЖИТТЯ ГРОМАДЯН
}

\begin{abstract}
Статтю присвячено аналізу сучасного стану та рекомендаціям щуодо вдосконалення механізмів взаємодії органів публічної влади з громадськістю для формування безпечного середовища життя громадян. Участь громадських організаиій і сочіально відповідальних громадян у забезпеченні начіональної безпеки дасть змогу уникнути відчуження між держсавними установами та інститутами громадянського суспільства, яке нині тільки посилюється. Ідея налагодження тісної взаємодії органів влади з інститутами громадянського суспільства, які мають необхідний потенщіал у запобіганні загрозам національної безпеки і досягненні високого рівня захищеності начіональних інтересів, видається иілком можливою в умовах наростання сучасної соиіально-економічної кризи. Національна безпека України безпосередньо залежить від рівня участі громадян у політичних проиесах, але тільки за умови, що вони не виходять за межі конституційно-правового поля. У статті наголошується, щчо в українському суспільстві чітко спостерігається зростання зачікавленості молоді політикою, тими важливими проиесами, які в ній відбуваються. Тому стає дедалі помітнішою активізачія політичної діяльності молодіжних громадських організацій, яка знаходить своє вираження в безпосередній їх участі в політичних подіях, шчо відбуваються в суспільстві. У статті робиться висновок, щчо дієвими механізмами підвищення ефективності взаємодії державної системи безпеки та громадських об' єднань сприяння безпеці є: участь державних органів України в консультативній діяльності та вдосконаленні системи підбору та підготовки кадрів для недержавних суб'єктів забезпечення безпеки; прикомандирування співробітників изих органів до найбільш ефективних суспільних структур для координації співпраці та спільного вирішення завдань щзодо забезпечення безпеки; подальше вдосконалення організаційних форм взаємодії між органами державного управління $і$ громадськими об'єднаннями за сприяння безпеці.
\end{abstract}

Ключові слова: безпечне середовище, безпека, безпека життєдіяльності.

Fedorova Anna. Current state and recommendations for improving the mechanisms of interaction between public authorities and the public to create a safe living environment for citizens

Participation of public organizations and socially responsible citizens in ensuring national security will avoid alienation between state institutions and civil society institutions, which is only getting worse now. The idea of establishing close interaction between government bodies and civil society institutions that have the necessary potential to prevent threats to national security and achieve a high level of protection of national interests seems quite possible in the context of the growing modern socio-economic crisis. The national security of Ukraine directly depends on the level of participation of citizens in political processes, but only if they do not go beyond the constitutional and legal framework. The article notes that in Ukrainian society there is clearly an increase in the interest of young people in politics, the important processes that take place in it. Therefore, the activation of political activities of youth public organizations is becoming more and more noticeable, which is expressed in their direct participation in political events taking place in society. The article concludes that effective mechanisms for improving the effectiveness of interaction between the state security system and Public Associations of security assistance are: participation of state bodies of Ukraine in advisory activities and improvement of the system of recruitment and training of personnel for non-state security actors; secondment of employees of these bodies to the most effective public structures to coordinate cooperation and joint solution of security tasks; further improvement of organizational forms of interaction between public administration bodies and public associations with the assistance of security.

Key words: safe environment, safety, life safety.

Останнім часом Україна стикається з загрозами ії безпеці, яких більшає, стає дедалі актуальнішим пошук нових резервів для ії забезпечення. Одним із таких ресурсів, які ще не отримали належного визнання свого потенціалу з боку держави 3 метою його використання в системі національної безпеки, є інститути громадянського суспільства. Значна їх частина нині функціонує як доцентрові сили, спрямовані на зміцнення соціальних зв'язків між різними суспільно-політичними складниками українського соціуму. Вони є важливою складовою частиною громадянського суспільства, яке являє собою 
систему добровільно сформованих об'єднань і організацій. Певною мірою діяльність цих асоціацій і громадських структур не залежна від державної влади (вона регулюється сформованими політичними традиціями і чинною нормативно-правовою базою) і спрямована на вирішення соціально значущих завдань, у тому числі пов'язаних із забезпеченням національної безпеки.

Проблема спільної діяльності інститутів громадянського суспільства і держави щодо забезпечення безпеки потребує концептуального поглиблення її аналізу. Вихідним принципом тут може виступити теза Н.Л. Розенблюма, що для безпечного цивілізаційного розвитку політичної системи сучасна держава має забезпечити відкритий зворотний зв' язок зі структурами громадянського суспільства [1, с. 21]. Адже без них навряд чи можливе їі повноцінне забезпечення. Відповідно, ресурс впливу інститутів громадянського суспільства на підвищення рівня національної безпеки міг би бути набагато вищим, ніж $є$ нині.

Участь громадських організацій і соціально відповідальних громадян у забезпеченні національної безпеки дасть змогу уникнути відчуження між державними установами та інститутами громадянського суспільства, яке нині тільки посилюється. Усвідомлення об'єктивної необхідності цього справить позитивний вплив як на позицію самих державних структур (чиї керівники часто насторожено ставляться до діяльності незалежних громадських об'єднань), включених у систему безпеки, так і на настрої значної частини українських громадян, стимулюючи їх до солідаризації, самоорганізації та створення громадських асоціацій для того, щоб захистити життєво важливі інтереси українського етносу. Інститути громадянського суспільства мають зайняти ключові місця в забезпеченні національної безпеки країни. Цей концептуальний підхід варто розглядати як більш прийнятний для сучасного стану українського суспільства, справді демократичний варіант регулювання українською владою багатомірного соціально-політичного простору в цілях забезпечення його безпеки.

Ідея налагодження тісної взаємодії органів влади з інститутами громадянського суспільства, які мають необхідний потенціал у запобіганні загроз національної безпеки і досягненні високого рівня захищеності національних інтересів, видається цілком можливою в умовах наростання сучасної соціально-економічної кризи. Громадянське суспільство містить у собі значний потенціал для формування цінностей громадянського миру і злагоди, необхідних для забезпечення сталого розвитку країни. В українському суспільстві політичне значення інститутів громадянського суспільства стає більш вагомим, оскільки посилюються соціально-економічні проблеми, які об'єктивно вимагають їх участі у вирішенні гострих питань, пов'язаних із необхідністю модернізаційного прориву. Рівень соціально-політичної відповідальності має поступово зміщуватися від державних структур в їх бік. Оскільки з урахуванням рівня освіти, політичної, соціальної активності певної частини суспільства можна стверджувати, що рівень впливу на формування думок і настроїв у суспільстві в інститутів громадянського суспільства великий.

Вітчизняні дослідники виділяють низку напрямів діяльності асоціацій громадян, пов'язаних із протидією загрозам національній безпеці: позитивний вплив на політичні і соціально-економічні процеси в Україні (наприклад, участь у воєнно-патріотичному вихованні молоді, благодійна діяльність, волонтерський рух); сприяння в розвитку державних інститутів (громадські палати в суб'єктах України; громадські комісії, створені при державних установах; громадська експертиза); конструктивна взаємодія 3 державними і регіональними органами влади щодо забезпечення національної безпеки; виявлення національних інтересів, політичних цілей і соціальних цінностей громадян, а також надання їм допомоги у визначенні власної стратегії суспільно корисної діяльності (релігійні організації, політичні партії, спортивні об’єднання).

Інститути громадянського суспільства і держави здатні спільно боротися з такими загрозами національній безпеці України: посиленням міжетнічної та міжнаціональної напруженості, криміналізацією суспільних відносин, екстремізмом і тероризмом, ксенофобією і націоналізмом, соціально-економічними проблемами, зниженням рівня фізичного здоров'я населення, погіршенням екологічної ситуації.

Розглядаючи юридичні аспекти втілення в життя концепції національної безпеки, пропонується закріпити відповідні повноваження за органами місцевої влади, розділивши вирішення завдань у сфері iii забезпечення органами місцевого самоврядування на прямо і побічно спрямовані. До «прямих» завдань органів місцевого самоврядування можна зарахувати такі: профілактику, мінімізацію соціальної напруги, нівелювання екстремізму та ксенофобії, здійснення заходів із цивільної оборони, участь у ліквідації наслідків надзвичайних ситуацій, організацію та здійснення заходів щодо забезпечення первинних заходів пожежної безпеки, реалізацію заходів із мобілізаційної підготовки регіональних установ. До числа завдань національної безпеки, які побічно сприяють ії̈ забезпеченню, вона зараховує: соціальну підтримку малозабезпечених громадян та поліпшення їхніх житлових умов, створення необхідних умов для житлового будівництва, організацію дозвілля жителів регіону та їх забезпечення послугами закладів культури, збереження та популяризацію об'єктів культурної спадщини, охорону 
об’єктів культурної спадщини місцевого значення, організацію та проведення офіційних спортивних та фізкультурно-оздоровчих заходів, реалізацію заходів по роботі з дітьми та молоддю, сприяння у працевлаштуванні громадян, забезпечення зайнятості неповнолітніх громадян у віці від 14 до 18 років, сприяння національно-культурному розвитку народів України. Таким чином, надається велике значення діяльності органів місцевого самоврядування щодо забезпечення національної безпеки, віднісено більшу частину їхніх функцій до області.

Своє концептуальне обгрунтування отримала необхідність посилення ролі громадських об'єднань у збереженні міжнаціонального миру і злагоди, а також у протидії спробам послаблення державної єдності української держави, запобіганні етнічній і релігійній ворожнечі.

Концептуальне осмислення отримали проблеми ролі релігійних організацій у справі забезпечення національної безпеки. Дослідники звертають увагу на те, що вони здатні брати активну участь у реалізації завдань забезпечення безпеки держави, і як аргументи наводять історичні факти, які свідчать про позитивну роль церкви в суспільстві. Нині це проявляється у створенні єдиної української автокефальної церкви та наданні Томосу Україні. Запобігання або захист від загрози міжконфесійної ворожнечі, здійснювані релігійними громадськими організаціями, є одними з найважливіших завдань забезпечення національної безпеки.

Зазначаючи роль соціально орієнтованих НКО як інституту сфери забезпечення національної безпеки, дослідники вказують на той факт, що через ці організації населення доносить свої вимоги до органів влади. Як суб'єкти громадянського суспільства вони здатні оперативно реагувати на гострі соціально-економічні проблеми населення, представляти інтереси різних соціальних груп і завдяки механізмам громадського контролю впливати на роботу представників органів влади. У сфері реалізації соціальної політики ці організації, як правило, здійснюють комплекс заходів, спрямованих на надання допомоги соціально незахищеним верствам населення. Ці заходи сприяють пом'якшенню і подоланню важких життєвих умов громадян, підтримують їх соціальний статус, тим самим забезпечуючи національну безпеку. Варто погодитися з оцінкою, що некомерційні організації розробляють і досить ефективно реалізують соціальні програми залежно від конкретних потреб різних груп населення. Адже через НКО виявляється суттєва допомога громадянам, для яких створюються соціальні служби, кризові центри, притулки, групи самодопомоги, ресурсні та молодіжні центри, благодійність і т. д. Впровадження цих організацій у систему національної безпеки $є$ важливою умовою її вдосконалення. Необхідно, щоб держава створила сприятливі умови для цього типу суспільних об’єднань, оскільки це дасть змогу поліпшити соціально-політичну ситуацію в українському суспільстві.

Національна безпека України безпосередньо залежить від рівня участі громадян у політичних процесах, але тільки за умови, що вони не виходять за межі конституційно-правового поля. Політологи звертають особливу увагу на те, що «владні режими демократичного спрямування мають на увазі причетність громадян до формальних і неформальних політичних процесів за допомогою політичної участі, яке виражається в таких політичних феноменах, як політична активність, політична діяльність, політична поведінка і т. д. Державна влада має прагнути направити активність громадян у конструктивне русло і ні в якому разі не ігнорувати або, більш того, намагатися нівелювати іiі. Варто погодитися 3 позицією дослідників, що завдання, яке стоїть перед органами влади та суспільством, полягає в тому, щоб, активізуючи діалог влади з інститутами громадянського суспільства за напрямами забезпечення національної безпеки, спрямувати політичну активність громадян у творче русло.

Очевидно, що партії і суспільно-політичні рухи різних форм і типів справляють істотний вплив на стан системи національної безпеки України. Причому цей вплив може бути як позитивним i, відповідно, підтримувати стабільність державно-політичної системи, так і спрямованим на її дестабілізацію. Варто зазначити, що альтернативні спрямованості суспільно-політичних рухів є відповідною реакцією на реалізований у країні політичний курс не тільки самих громадян, але і зовнішніх сил, зацікавлених у зміні політичного курсу країни. Проте не варто всі опозиційні суспільно-політичні рухи однозначно тлумачити як деструктивні. Через діалектичне заперечення того, що заважає суспільству ефективно функціонувати, і можлива стабільність її політичної системи. Це не поширюється на ідеологічні та політичні течії радикальної спрямованості, основним завданням яких $є$ не легальне усунення недоліків чинного політичного режиму, а створення в країні хаосу, що ставить серйозну загрозу існуванню українського етносу.

В українському суспільстві чітко спостерігається зростання зацікавленості молоді політикою, тими важливими процесами, які в ній відбуваються. Тому стає більш помітною активізація політичної діяльності молодіжних громадських організацій, яка знаходить своє вираження у безпосередній їх участі в політичних подіях, що відбуваються в суспільстві. Підвищення інформованості про політичну 
обстановку зумовлює зміну образу думки молоді, зменшується ії конформізм, переосмислюється стереотипний погляд на багато проблем. Політична активізація молоді опосередковано пов'язана зі станом національної безпеки в Україні. Адже молодь $є$ стратегічним і тактичним ресурсом не тільки для правлячого режиму, але і для представників опозиційних сил. 3 одного боку, вона може своєю політичною активністю підтримувати політичну систему, забезпечуючи ії сталий розвиток, тим самим зміцнюючи національну безпеку країни, а $з$ іншого - може стати джерелом дестабілізації суспільно-політичної системи, опинившись під впливом чужих національним інтересам сил, що фінансуються олігархією.

Аналізуючи механізми взаємодії органів влади та молодіжних суспільно-політичних об'єднань у галузі забезпечення національної безпеки, визначають найбільш поширені форми участі цих рухів в українському політичному процесі, які дають змогу виразити цілий спектр політичних поглядів молоді: членство в молодіжних парламентських органах, молодіжних урядах, обговорення законотворчих ініціатив, участь і створення «медійних» суспільно-політичних кампаній, масових акцій, проведення форумів, круглих столів, на яких обговорюються важливі громадські та політичні проблеми і питання, пов'язані із забезпеченням національної безпеки. Молодіжний парламент як одна 3 технологій громадської участі у процесі прийняття соціально-політичних рішень може служити ефективним інструментом політичної соціалізації, що сприяє зміцненню національної безпеки.

Таким чином, дослідники надають великого значення взаємодії інститутів держави і громадянського суспільства у справі забезпечення національної безпеки України, концептуально обгрунтовуючи необхідність їх спільної діяльності в цьому напрямі. Вони визнають, що цей потенціал реалізується ще далеко не повною мірою. Можна виділити два основних концептуальних підходи (ліберальний і етатистський), до яких тяжіють вітчизняні дослідники. Прихильники ліберального підходу виступають за домінування інтересів інститутів громадянського суспільства в процесі розвитку системи національної безпеки і за їх рівноправну співпрацю з державними структурами. Прихильники етатистської концепції відстоюють безумовний пріоритет державних органів у формуванні системи національної безпеки.

Дієвими механізмами підвищення ефективності взаємодії державної системи безпеки та громадських об'єднань сприяння безпеці є:

- участь державних органів України в консультативній діяльності та вдосконаленні системи підбору та підготовки кадрів для недержавних суб’єктів забезпечення безпеки;

- прикомандирування співробітників цих органів до найбільш ефективних суспільних структур для координації співпраці та спільного вирішення завдань щодо забезпечення безпеки;

- подальше вдосконалення організаційних форм взаємодії між органами державного управління і громадськими об'єднаннями за сприяння безпеці, що дає змогу подолати вузькокорпоративний характер і відомчу роз'єднаність нинішніх установ координації державних і громадських інститутів у сфері безпеки, та їх інтеграція в систему державних і регіональних структур протидії загрозам національним інтересам.

Тема об'єднання зусиль цивільних інститутів у справі захисту державної, громадської та особистої безпеки в України дуже актуальна. За цей час накопичено унікальний досвід організації діяльності недержавної системи забезпечення безпеки. Це значна сила, що не тільки здатна у співпраці з правоохоронними органами ефективно боротися з тероризмом і злочинністю, але і робити посильний внесок у захист практично всіх сфер життєдіяльності.

Відсутність належної координації спільних дій органів влади та певних елементів недержавної системи забезпечення безпеки є нині причиною як неефективної діяльності самих органів влади щодо захисту інтересів особистості, суспільства і держави, так і неоптимального розподілу функцій між самими органами влади, відомствами, міністерствами, покликаними вирішувати завдання забезпечення національної безпеки України. У таких важливих законодавчих актах України, як закони «Про боротьбу 3 тероризмом» [2], «Про оборону України» [3], не прописані параметри і критерії співпраці з громадськими структурами, що сприяють вирішенню важливих проблем оборонної політики і безпеки.

Процес формування оптимальної моделі взаємодії між державою і громадськими об’єднаннями має передбачати продуманий комплекс заходів нормативно-правового та організаційно-штатного характеру, що охоплює всі сторони їх практичних проявів і забезпечує їхню прозорість стосовно держави та контролю з боку громадян. Ми вважаємо, що така мета може бути досягнута шляхом раціонально організованої, юридично обгрунтованої інтеграції елементів об’єднань у сфері сприяння безпеці в структуру державних та громадських інститутів, об’єднання різнорідних типів в єдині структурні утворення, зі збереженням розумних меж автономії, досягнутої ними за попередній період. У зв'язку з цим необхідно внести поправки в законодавчу базу, прийняти нові нормативні акти, націлені на виділення конструктивних елементів і відсіювання організацій, які не переслідують продуктивних цілей.

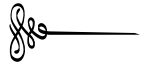


Питання про подальшу еволюцію громадських об'єднань у сфері сприяння безпеці в України нині залежить від комплексу умов і факторів, здатних серйозно впливати на динаміку розвитку сучасних політичних процесів. На нашу думку, найбільш актуальними з них варто визнати невирішеність проблеми забезпечення національної безпеки, суперечливий характер сучасної політики вищого керівництва держави, яка продовжує відрізнятися непослідовністю, прихильністю стереотипам, відсутністю творчого підходу у визначенні основних пріоритетів взаємодії органів влади і громадських інститутів у сфері захисту національних інтересів. Оцінка результатів діяльності правлячих кіл не дає підстав для констатації наявності осмисленої стратегії з оптимізації проблем національної безпеки, в основі якої був би повноцінний методологічний конструкт, що поєднує в собі інноваційні моделі військовополітичного будівництва та реалії української практики, найбільш ефективні зарубіжні зразки і досвід вітчизняних традицій.

Необхідно оптимізувати функціонування громадських об'єднань у сфері протидії загрозам національним інтересам, створити сучасні інститути, що поєднують інноваційні технології і вітчизняні традиції, здатні вирішувати комплексні завдання щодо забезпечення національної безпеки, надання цивілізованого характеру процесу формування недержавної системи безпеки, досягнення національної злагоди, сприяння інтеграції громадянського суспільства і держави.

Таким чином, важливим фактором у вирішенні завдань забезпечення національних інтересів держави та протидії загрозам і небезпекам є створення системи всебічної та якісної взаємодії між суб'єктами забезпечення безпеки держави на основі партнерства. Для досягнення цієї мети потрібне адекватне правове, інформаційне, матеріально-технічне забезпечення, а також чітка взаємодія громадських структур із міжвідомчими органами державного управління.

\section{Література:}

1. Розенблюм Н.Л. Громадянські суспільства: лібералізм і моральні впливи плюралізму. Культурологічний часопис «Ї»: Громадське суспільство. 2011. № 21. С. 6-29.

2. Про боротьбу з тероризмом : Закон України № 638-IV, ред. від 04.11.2018 p. URL: http://zakon.rada.gov.ua/laws/ show/638-15.

3. Про оборону України : Закон України № 1932-XII, ред. від 04.11.2018 p. URL: http://zakon.rada.gov.ua/laws/ show/1932-12. 